\title{
PEMANFAATAN CITRA MODIS LEVEL 1B DALAM PEMBUATAN PETA PRAKIRAAN DAERAH PENANGKAPAN IKAN \\ (Studi Kasus : Pantai Selatan Blitar)
}

\author{
Bangun Muljo Sukojo ${ }^{1}$, Eva Resti Febriani ${ }^{1}$ \\ ${ }^{1}$ Departemen Teknik Geomatika, FTSLK-ITS, Kampus ITS Sukolilo, Surabaya, 60111, Indonesia \\ e-mail: ${ }^{1}$ bangun_ms@geodesy.its.ac.id
}

\begin{abstract}
Abstrak
Pengaruh fenomena El Nino juga dapat dipelajari dan dianalisis menggunakan data fluktuasi pasang surut di permukaan laut. Pasang surut adalah naik turunnya permukaan laut disebabkan oleh kombinasi gaya gravitasi dari rotasi bulan, matahari dan Bumi. Selain itu, perubahan suasana seperti perubahan tekanan, angin dan suhu akan mempengaruhi pola pasang surut dan aktivitas pasang surut. Hasil kajian menunjukan penurunan MSL selama terjadi El Nino di Perairan Surabaya mengikuti persamaan linier dengan persamaan $y=114.1-0.3782 x(R 2=20,69 \%)$ dengan penurunan MSL sebesar 4,347 cm sepanjang 2014-2015.
\end{abstract}

Kata Kunci : El Nino, MSL (Mean Sea Level), SPL (suhu permukaan laut), Surabaya

\begin{abstract}
The potential of marine resources in Blitar quite large but utilization is not optimal, so it requires a Regional Forecast Map Fishing in order to exploit the potential of fishery resources there is more optimal. Determination of the area forecast use of the fish can be predicted from the parameters of sea surface temperature and chlorophyll-a. Modis image level $1 b$ can be used in the manufacture of the forecast utilization of fish pennagkapan area. Used algorithm ATBD (Theoretical Basic Document Encryption Modis) 25 to determine sea surface temperature and Algorithms Morel 4 is used to determine the chlorophyll-a. The results obtained from this study is the RMSE test conducted between field data with the data Modis image of RMSE $1 \mathrm{~b}$ level of 0.706568 , with forecasts of fishing areas and potentially potent enough.
\end{abstract}

Keywords - image, fishing ground, sea surface temperature, chlorophyll-a

\section{PENDAHULUAN}

Kabupaten Blitar memiliki pantai yang terbentang sepanjang $45 \mathrm{~km}$ dengan luas 4 mil laut $=26.100$ $\mathrm{Ha}$, luas 12 mil laut $=63.330 \mathrm{Ha}$, dan luas ZEE = 1.305.500 Ha. Hal ini berarti potensi sumber daya laut yang ada di Kabupaten Blitar untuk 4 mil laut mencapai 1.044 ton/tahun, untuk 12 mil Laut mencapai 3.133 ton/tahun dan ZEE sebesar 52.220 ton/tahun. Kabupaten Blitar memiliki potensi perikanan yang cukup besar, baik perikanan darat (air tawar) maupun perikanan laut. Potensi ikan laut disana cukup menjanjikan, lantaran Kabupaten Blitar berbatasan dengan samudera Indonesia di bagian selatan. Namun sampai sekarang pemanfaatan oleh nelayan Kabupaten Blitar atas potensi tersebut baru mencapai $10 \%$ dari potensi laut yang ada. Oleh karena itu, dengan potensi yang besar dan pemanfaatan yang belum optimal diperlukan sebuah Peta Prakiraan Daerah Penangkapan Ikan untuk dapat memanfaatkan potensi sumberdaya perikanan disana secara optimal.

Untuk mendukung upaya pengembangan perekonomian Indonesia dalam bidang kelautan, salah satu upaya yang dilakukan adalah pemanfaatan sumberdaya perikanan yang optimal. Pemanfaatan sumberdaya perikanan di indonesia kalah dengan negara tetangga yang memiliki luas lautan yang jauh lebih kecil dibanding indonesia. Dengan menggunakan teknologi penginderaan jauh atau remote sensing, saat ini kita telah dapat melakukan penglihatan pada cakupan wilayah yang sangat luas tanpa menyentuh benda tersebut dan dilakukan dengan waktu yang sangat singkat. Teknologi inilah yang dapat digunakan untuk menentukan posisi daerah potensi ikan. Sebaran klorofil-a dan suhu permukaan laut inilah yang merupakan indikator tingkat kesuburan perairan dan kelimpahan makanan bagi ikan. Salah satu instrumen yang dapat digunakan untuk mendeteksi keberadaan 
klorofil dan suhu permukaan laut yaitu citra satelit Modis.

Citra Modis memiliki 3 jenis data citra yaitu Citra Modis level 1a, 1b, 2, dan 3. Dalam penelitian ini kita menggunakan Citra Modis level $1 b$ dan level 2. Level 1 merupakan data mentah yang akan di proses menggunakan aloritma untuk memisahkan data - data yang terdapat pada Citra Aqua Modis. Level $1 b$ adalah data yang telah mempunyai terapannya, hasil dari kalibrasi sensor pada level 1a. Citra Modis level $1 \mathrm{~b}$ ini merupakan salah satu citra yang dapat digunakan untuk membuat peta prakiraan daerah penangkapan ikan dengan parameter suhu permukaan laut dan klorofil-a. Untuk melihat sebaran klorofil-a digunakan algoritma MOREL 4 karena algoritma ini merupakan yang paling baik dari beberapa algoritma untuk mencari sebaran klorofil-a [1] . Sedangkan untuk melihat sebaran suhu permukaan laut kita menggunakan algoritma ATBD_25.

\section{METODOLOGI PENELITIAN}

Lokasi penelitian ini mengambil daerah studi di perairan Pantai Selatan Blitar dan sekitarnya. Secara geografis terletak pada $8^{\circ} 15^{\prime} 0^{\prime \prime}-8^{\circ} 27^{\prime} 0^{\prime} \mathrm{LS}$ dan $112^{\circ} 0^{\prime} 0^{\prime}-112^{\circ} 15^{\prime} 0^{\prime}$ BT dalam penelitian berada pada posisi

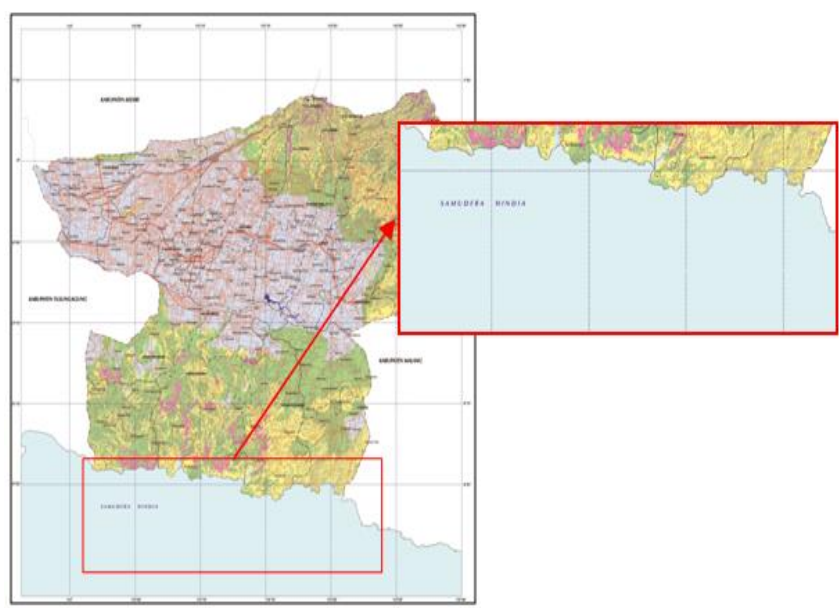

Gambar 1 Lokasi Daerah Penelitian

(Sumber : Citra Modis Level 1b)

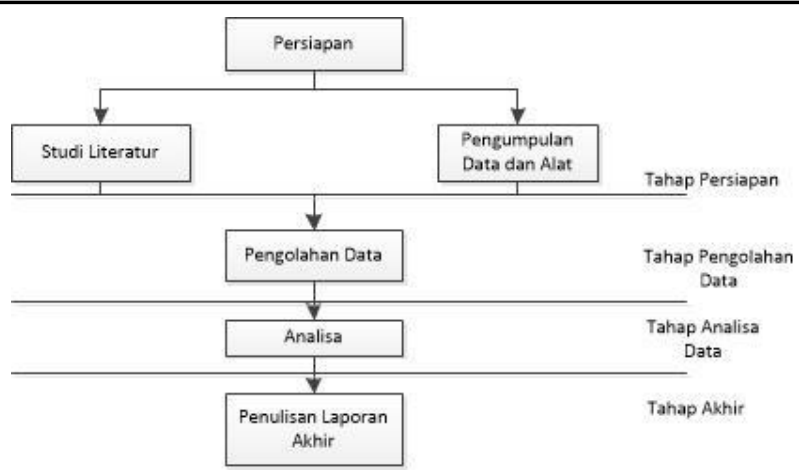

Gambar 2. Diagram Alir Penelitian

Adapun tahap penelitian digambarkan secara umum dengan penjelasan sebagai berikut:

1. Tahap Persiapan

-Identifikasi Awal

Bertujuan untuk mengidentifikasi permasalahan yang diangkat sebagai tema penelitian, objek penelitian dan daerah penelitian serta merumuskan cara memecahkan permasalahan tersebut. Adapun permasalahan dalam penelitian ini adalah bagaimana perbandingan penggunaan Citra Modis level $1 \mathrm{~b}$ dalam menentukan prakiraan daerah penangkapan ikan di Pantai Selatan Blitar.

-Studi Literatur

Studi Literatur dilakukan untuk mempelajari dan mengumpulkan referensi dan hasil penelitian sejenis sebelumnya yang pernah dilakukan orang lain yang berkaitan sebagai dasar teori mengenai masalah yang akan diteliti suhu permukaan laut, klorofil, fishing ground, dan literatur lainnya yang mendukung baik dari buku, jurnal, majalah, internet dan lain sebagainya.

- Pengumpulan Data

Pengumpulan data berupa peta vektor Rupabumi Indonesia skala 1:1.000.000 dan data lapangan suhu permukaan laut dan klorofil-a.

2. Tahap Pengolahan Data

Pada tahapan ini dilakukan pengolahan dari data yang telah diperoleh dan data penunjang lainnya.

3. Tahap Analisa

Data yang telah diolah kemudian dianalisis sehingga di dapatkan suatu hasil prakiraan 
daerah penangkapan ikan Citra menggunakan Modis level $1 \mathrm{~b}$.

4. Tahap Akhir

Penyusunan laporan merupakan tahap akhir dari proses penelitian ini sebagai laporan penelitian ini disertai dokumentasi dari pelaksanaan penelitian.

\section{HASIL DAN PEMBAHASAN}

Dari koreksi geometrik yang dilakukan dengan menyebar titik-titik GCP diperoleh RMS error keseluruhan yaitu sebesar 0,417766. Proses korekis geometrik pada citra ini sudah memenuhi toleransi batas kesalahan koreksi geometrik $\leq 1$ piksel.

Nilai strength of figure dari titik kontrol registrasi citra untuk setiap citra yang digunakan adalah sebesar 0,1532. Dalam hal ini semakin kecil bilangan faktor kekuatan jaringan tersebut, maka akan semakin baik konfigurasi jaringan yang bersangkutan .

Hasil RMS error mempunyai nilai kurang dari satu piksel dan SoF mendekati nol sehingga dianggap memenuhi syarat yang diberikan.

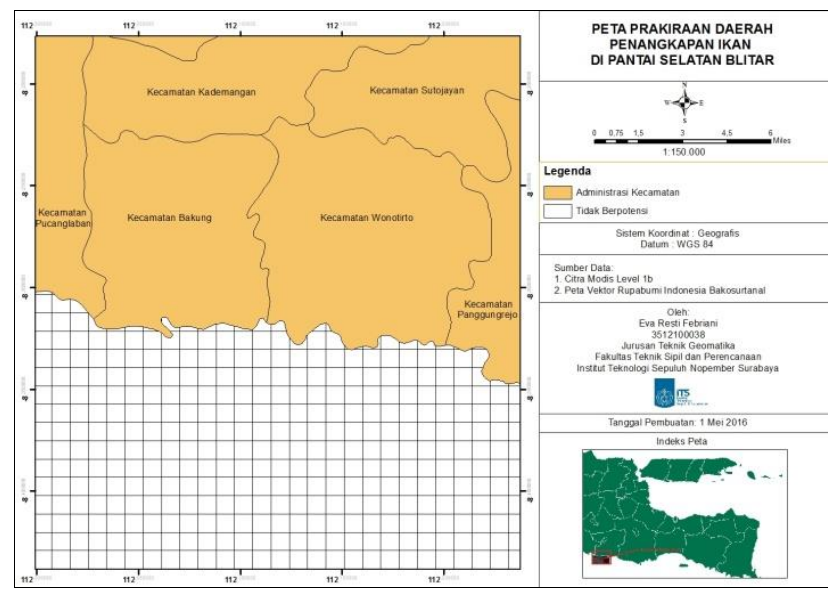

Gambar 4. Peta PDPI Menggunakan Modis Level 1b

Data lapangan yang telah didapatkan dinputkan pada citra yang terkoreksi geometrik, diperoleh data yang sesuai dengan piksel citra.

Tabel 1. Data Lapangan

\begin{tabular}{|c|c|c|c|c|}
\hline \multirow{2}{*}{ No } & \multicolumn{2}{|c|}{ Koordinat } & \multicolumn{2}{c|}{ Data Lapangan } \\
\cline { 2 - 5 } & Bujur & Lintang & $\begin{array}{l}\text { Klorofil-a } \\
(\mathrm{mg} / \mathrm{l})\end{array}$ & SPL $\left({ }^{\circ} \mathrm{C}\right)$ \\
\hline \multirow{2}{*}{1} & 112,15448610 & $-8,34657417$ & 0,174 & 29,6 \\
\hline
\end{tabular}

\begin{tabular}{|c|c|c|c|c|}
2 & 112,15591390 & $-8,35545556$ & 0,203 & 28,6 \\
\hline 3 & 112,14653060 & $-8,35405556$ & 0,145 & 27,6 \\
\hline 4 & 112,14653060 & $-8,35320556$ & 0,144 & 27 \\
\hline 5 & 112,13261110 & $-8,35235000$ & 0,232 & 28,6 \\
\hline 6 & 112,12334170 & $-8,35136111$ & 0,087 & 30,8 \\
\hline 7 & 112,11286110 & $-8,35102778$ & 0,23 & 29 \\
\hline 8 & 112,10230560 & $-8,34973056$ & 0,205 & 29,4 \\
\hline 9 & 112,10541110 & $-8,34581111$ & 0,21 & 29,4 \\
\hline 10 & 112,11424440 & $-8,33843056$ & 0,175 & 28,6 \\
\hline
\end{tabular}

Suhu permukaan laut, konsentrasi klorofil, arus laut, salinitas air laut, dan kandungan oksigen terlarut, fenomena upweeling dan front menjadi indikasi lokasi fishing ground, dimana daerah tersebut menandakan adanya fitoplankton yang merupakan makanan bagi ikan. Selain itu, terdapat juga faktor-faktor lain yang dapat mempengaruhi lokasi fishing ground ini. Dalam penelitian ini, untuk mencari atau menentukan suatu area fishing ground digunakan parameter sebaran klorofil-a dan juga suhu permukaan laut.

Dalam penelitian ini digunakan uji RMSE. Uji RMSE merupakan salah uji yang digunakan untuk mencerminkan perbedaan antara data lapangan dengan data ekstraksi citra.

Tabel 2. Uji RMSE antara Data Lapangan dengan Data Citra Modis Level 1b

\begin{tabular}{|c|c|c|c|c|c|}
\hline \multirow[b]{2}{*}{ No } & \multicolumn{2}{|c|}{ Citra } & \multicolumn{2}{|c|}{ Lapangan } & \multirow[b]{2}{*}{ RMS } \\
\hline & $X(\mathrm{mg} / \mathrm{l})$ & $\mathrm{Y}\left({ }^{\circ} \mathrm{C}\right)$ & $\begin{array}{c}x \\
(\mathrm{mg} / \mathrm{l})\end{array}$ & $\begin{array}{c}y \\
\left({ }^{\circ} \mathrm{C}\right)\end{array}$ & \\
\hline 1 & 0,145 & 26,634 & 0,174 & 29,6 & 1,117793 \\
\hline 2 & 0,140 & 24,887 & 0,203 & 28,6 & 1,237958 \\
\hline 3 & 0,143 & 29,731 & 0,145 & 27,6 & 0,710326 \\
\hline 4 & 0,145 & 29,731 & 0,144 & 27 & 0,910325 \\
\hline 5 & 0,145 & 29,883 & 0,232 & 28,6 & 0,299038 \\
\hline 6 & 0,146 & 32,228 & 0,087 & 30,8 & 0,476534 \\
\hline 7 & 0,147 & 30,732 & 0,23 & 29 & 0,486314 \\
\hline 8 & 0,147 & 30,732 & 0,205 & 29,4 & 0,050060 \\
\hline 9 & 0,148 & 30,732 & 0,21 & 29,4 & 0,331794 \\
\hline 10 & 0,146 & 27,188 & 0,175 & 28,6 & 1,445539 \\
\hline & & & & & 0,706568 \\
\hline
\end{tabular}

Dari data uji RMSE antara data lapangan dengan data citra Modis level $1 \mathrm{~b}$ didapatkan nilai RMSE sebesar 0,706568. Batas toleransi untuk nilai kesalahan RMSe adalah $\leq 1$ pixel, 
sehingga apabila nilai RMSe lebih besar dari 1 pixel (Purwandhi 2001). Muhsoni juga mengatakan bahwa semakin kecil nilai RMS error maka data yang didapat semakin bagus dan akurat. Jadi uji RMSE RMSE antara data lapangan dengan data citra Modis level $1 \mathrm{~b}$ memenuhi batas toleransi.

\section{KESIMPULAN}

Berdasarkan hasil analisa penelitian ini yang telah di kemukakan, maka dapat diambil kesimpulan sebagai berikut :

- Dari pengolahan data yang dilakukan didapatkan hasil area fishing ground pada citra Modis level $1 \mathrm{~b}$ dengan daerah semuanya tidak berpotensi.

- Nilai uji RMSE Citra Modis level 1b dengan dengan data lapangan sebesar 0,706568. Batas toleransi untuk nilai kesalahan RMSe adalah $\leq 1$ pixel, sehingga apabila nilai RMSe lebih besar dari 1 pixel (Purwandhi 2001). Muhsoni juga mengatakan bahwa semakin kecil nilai RMS error maka data yang didapat semakin bagus dan akurat.

\section{UCAPAN TERIMA KASIH}

Kami sampaikan terima kasih kepada kepada Departemen Geomatika ITS yang telah memberikan dukungan administrasi dan pendanaan sehingga penelitian ini dapat berjalan dengan baik dan lancar.

\section{DAFTAR PUSTAKA}

Prasasti, Indah, Bambang Trisakti, dan Uyum Mardiana. 2005. "Sensitifitas Beberapa Algoritma dan Kanal-kanal Data Modis untuk Deteksi Sebaran Klorofil." Pertemuan IImiah MAPIN XIV "Pemanfaatan Efektif Penginderaan Jauh untuk Peningkatan Kesejahteraan Bangsa".

Purwandhi, S H. 2001. Interpretasi Citra Digital. Jakarta: Grasindo.

Muhsoni, F.F. 2008. Tutorial Pengolahan Citra Digital (Menggunakan ENVI). Bangkalan: Jurusan Ilmu Kelautan Fakuktas Pertanian Universitas Trunojoyo. 